УДК 612.12-008.331-06:616]-089

DOI 10.11603/2414-4533.2016.3.6787

() К. М. МИЛИЦЯ ${ }^{1}$, О. А. ЛАВРИК², В. Є. БАХРУШИН ${ }^{3}$

дз “Запорізька медична академія післядипломної освіти МОЗ України”1

Національний інститут хірургії та трансплантології імені О. О. Шалімова НАМН України

Класичний приватний університет ${ }^{3}$, м. Запоріжжя

\title{
Хірургічне лікування метаболічного синдрому як профілактика розвитку мортальних захворювань
}

\author{
K. M. MYLYTSYA ${ }^{1}$, O. A. LAVRYK², V. YE. BAKHRUSHYN ${ }^{3}$
}

Zaporizhian Medical Academy of Post-Graduate Education ${ }^{1}$

O. Shalimov National Institute of Surgery and Transplantology ${ }^{2}$

Classic Private University ${ }^{3}$, Zaporizhzhia

\section{SURGICAL TREATMENT OF METABOLIC SYNDROME AS A PROPHYLAXIS OF MORTAL DISEASES DEVELOPMENT}

\begin{abstract}
У статті на підставі обстеження 40 пацієнтів у до- і післяопераційному періоді визначено ефективність баріатричних операцій, доведено хірургічну можливість попередження розвитку мортальних ускладнень у пацієнтів із метаболічним синдромом та ожирінням.

In the article on the basis of a survey of $\mathbf{4 0}$ patients before and after the operating period we defined the efficiency of bariatric surgery, proved the possibility of preventing the development of surgical mortal complications in patients with metabolic syndrome and obesity.
\end{abstract}

Постановка проблеми і аналіз останніх досліджень та публікацій. Метаболічний синдром (MC) є комплексом захворювань із загальною патогенетичною основою, яка клінічно реалізується в андроїдне ожиріння, інсулінорезистентність, гіперінсулінемію і артеріальну гіпертензію. Якщо кожне з вищеперелічених захворювань навіть само по собі становить загрозу здоров’ю і життю людини, то їх поєднання настільки підвищує ризик смертельного результату, що синонімом метаболічного синдрому став термін “смертельний квартет” [1, 2, 3].

Враховуючи, що поширеність МС серед населення різних країн Європи й Америки коливається від 10 до $25 \%$, стає зрозумілим, що боротьба за тривалість і якість життя населення безпосередньо пов'язана з успіхами в лікуванні метаболічного синдрому. Смертність від складових МС, зокрема від ожиріння, настільки висока, що в 2008 р. у Європейських клінічних рекомендаціях МС названий “безпрецедентною і недооціненою проблемою охорони здоров'я” у Європейському регіоні $[4,5]$.

До сьогодні численні медикаментозні препарати, способи і схеми лікування МС дають тимчасовий успіх i, в кращому разі, забезпечують стабілізацію процесу на час приймання препарату, перешкоджаючи прогресу одного або декількох складових синдрому. В останне десятиліття безумовну перевагу віддають хірургічному лікуванню метаболічного синдрому. Створений окремий напрям “метаболічна хірургія”, з 1991 р. випускається спеціалізований хірургічний журнал “Obesity Surgery”, а з часом з'явився і другий "Surgery for Obesity and related diseases". Усе це пов'язано $з$ тим, що на сучасному етапі розвитку медичної науки тільки хірургічне лікування МС дає довгострокові, надійні, комплаєнтні результати $[6,7,8]$. Так, проведений деякими авторами [9, $10,11]$ аналіз смертності у пацієнтів із цукровим діабетом 2 типу показав, що при проведенні шунтування шлунка смертність була на 92 \% нижча, ніж при консервативній терапії, а усунення гіперінсулінемії та інсулінорезистентності дозволило значно знизити ризик онкогенезу і передчасної смертності.

Безумовно, як завжди при хронічному перебігу захворювання, хірургічне втручання здійснюється при неефективності консервативної терапії і розвитку безпосередньої загрози життю пацієнта. Таким станом, $є$ поєднання МС із морбідним ожирінням (O), коли індекс маси тіла (IMT) пере- 
вищує або дорівнює 35 кг/м², або за наявності інших коморбідних станів [12].

Мета роботи: враховуючи все вищевикладене, метою цього дослідження стало визначення ефективності рестриктивних операцій у лікуванні мортальних складових метаболічного синдрому.

Матеріали і методи. Проаналізовано 40 спостережень за хворими на МС та О, яким було виконано баріатричні операції. У всіх пацієнтів було вивчено анамнез життя та захворювань, проведено антропометричні, загальноклінічні та лабораторно-інструментальні дослідження. Всі дослідження виконували стандартизовано. Визначали масу тіла пацієнтів, зріст, розраховували IMT. Обвід живота вимірювали на рівні пупка сантиметровою стрічкою. Всіх пацієнтів досліджено до і після операції. За типом операцій вони були розподілені так: гастроплікація - 21, лапароскопічна поздовжня резекція шлунка (ЛПРШ) 15, інші - 4. Вивчали також вміст у крові інсуліну, глюкози, індексу HOMA-IR. При цьому пацієнти з клінічним діагнозом діабету були виключені з дослідження. Повторне вивчення рівня інсуліну, глюкози в крові та індексу HOMA-IR проводили через 10-12 місяців після операції. Спостереження за пацієнтами здійснювали протягом від одного до трьох років. Інсулін та глюкозу визначали за стандартними методиками. Для оцінки інсулінорезистентності розраховували індекс НОМАIR за формулою: HOMA-IR = глюкоза натщесерце (ммоль/л) × інсулін натщесерце (мкОд/мл)/22,5. Нормативний показник менший за 2,7.

Сформовано 3 групи пацієнтів. Першу склали пацієнти з МС та О, яким було виконано гастроплікацію, другу - пацієнти з ЛПРШ, третю (контрольну) - 20 пацієнтів без ознак МС та О. Групи хворих були порівнянні за віком, гендерним співвідношенням, кількісною і якісною вибіркою супутніх захворювань. Вірогідна різниця у групах стосувалася лише IMT, який у першій групі до-

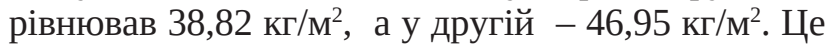
пояснюється тим, що у 2 групі були пацієнти, які свідомо прийшли на баріатричну операцію, заздалегідь ознайомилися з видами операцій, вибрали саме ЛПРШ та проходили передопераційну підготовку. А в першій групі 57,1 \% склали пацієнти із симультанною гастроплікацією, яку не можна проводити при дуже тяжких соматичних станах, що спостерігаються при морбідному ожирінні.

Методами статистичного аналізу перевіряли наявність впливу типу операції на нормалізацію значень показників, а також наявність парної кореляції між показниками. Враховуючи недостат- ньо великий обсяг вибірок, використовували тести та методи, що базуються на візуалізації даних за допомогою гістограм абсолютних частот, Q-Q діаграм, а також графіків емпіричних функцій розподілу, що дозволило забезпечити вірогідність даних $[13,14]$. Для попереднього порівняння значень показників щодо зазначених вибірок використовували діаграми за типом “ящик з вусами”, які будували за допомогою функції boxplot мови програмування R.

Результати досліджень та їх обговорення. Результати досліджень виявили, що різниці у середніх показниках росту пацієнтів 1 і 2 груп не спостерігалось (відповідно, 167,8 та 166,2 см). Середня маса пацієнтів 1 першої групи склала 109,9 кг, а 2 групи - 133,5 кг. Тобто різниця у IMT між пацієнтами 1 і 2 груп має місце лише за рахунок маси тіла. Надлишок маси тіла у групі $з$ гастроплікацією дорівнював 39,46 кг, а у групі 3 ЛПРШ - 64,22 кг.

Патогенетична дія баріатричних операцій полягає в зниженні кількості жирової маси i, відповідно, в зниженні механічної і агресивної метаболічної дії на організм пацієнта. Тому ефективність таких операцій оцінюється, перш за все, за втратою маси тіла. Аналіз результатів продемонстрував, що середня втрата маси тіла пацієнтів першої групи (гастроплікація) протягом року склала 25 кг, а другої (ЛПРШ) - 40 кг (рис. 1). Таким чином, середня післяопераційна маса пацієнтів знизилась до 85 кг у першій групі та до 94 кг - у другій. У відсотковому значенні при гастроплікації втрата маси склала 22 \%, а при ЛПРШ - 30 \% від первинної маси тіла. А післяопераційний індекс маси тіла дорівнював 30 кг $/ \mathrm{M}^{2}$ у першій і 34 кг $/ \mathrm{M}^{2} \mathrm{y}$ другій групі відповідно.

Але зниження маси тіла, навіть значне, ще не тотожне досягненню її нормалізації. Тому в роботі визначали та порівнювали IMT у до- та післяопераційному періодах. Результати наведено на рисунку 2.

Аналізуючи вищевикладені показники, складається враження, що ефективність операції подовжньої резекції шлунка значно вища, ніж у гастроплікації. Але при аналізі такого показника, як втрата маси тіла у відсотках від надлишкової маси тіла, ефективність поздовжньої гастроплікації складає 75,2 \% і перевищує показники поздовжньої резекції шлунка, в групі якої він дорівнює $66,76 \%$.

Зменшення кількості жиру в організмі має не тільки механічне значення (менша маса, менше навантаження на суглоби та хребет і т. ін.), але й 


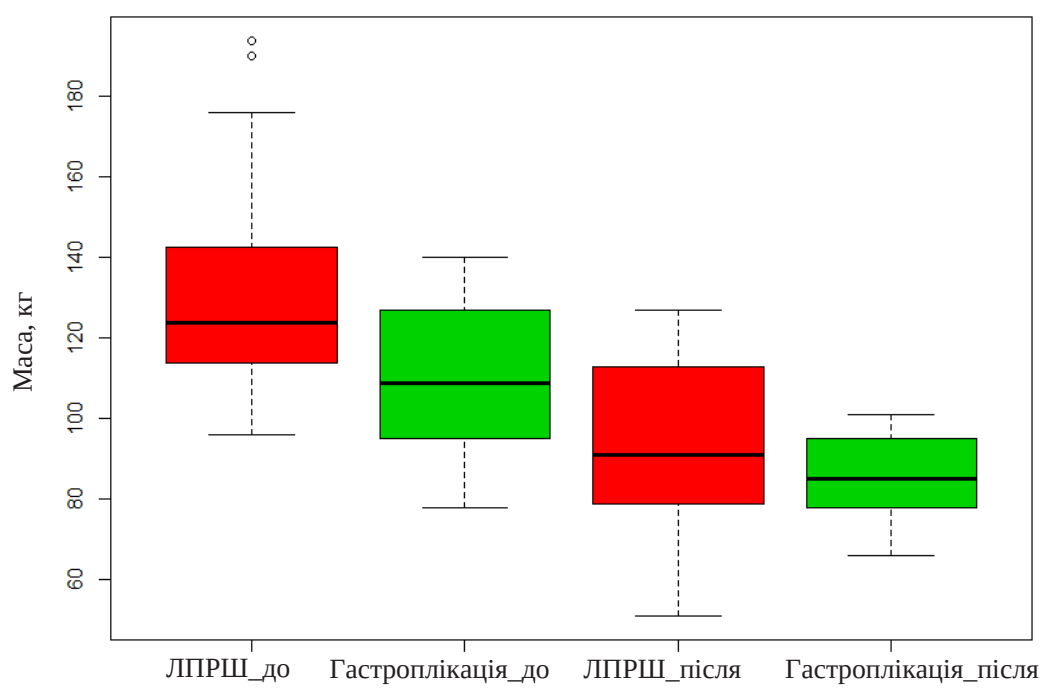

Рис. 1. Розподіл значень маси пацієнтів до і після операції.

метаболічне - зменшення агресивного впливу зайвої жирової тканини, що проявляється, перш за все, зсувами у стані вуглеводного обміну.

Визначення особливостей вуглеводного стану пацієнтів довело, що баріатричні операції дійсно чинять вплив на рівень вмісту в крові інсуліну, відновлюють сенситизацію рецепторів до інсуліну, що зумовлює нормалізацію стану інсулінорезистентності. Так, рівень глюкози крові у передопераційному періоді у пацієнтів обох груп істотно не відрізнявся (4,92 ммоль/л - група з гастроплікацією та 4,76 ммоль/л - група з ЛПРШ). У післяопераційному періоді в обох групах простежувалась тенденція до зниження рівня глюкози, але не вірогідна. Більше того, і в перед-, і в післяопераційному періодах показники глюкози не виходили за межі нормативних фізіологічних показників.
Щодо інсуліну, то тут ситуація змінюється. При передопераційному обстеженні середній рівень інсуліну у пацієнтів обох груп істотно не відрізнявся та наближався до верхньої межі нормативних показників (відповідно, 25,22 мкОд/мл у групі з гастроплікацією та 26,44 мкОд/мл у групі 3 ЛПРШ). У післяопераційному періоді спостерігається вірогідне зменшення вмісту інсуліну в крові: показник у першій групі знизився у 3,6 раза, а у другій - у 3,3 раза ( $<0,05 ; \mathrm{p}<0,05)$. Але при цьому показники не вийшли за межі нижнього порога фізіологічного значення і максимально наблизились до контрольних (рис. 3, 4).

Таким чином, середні показники і глюкози, й інсуліну у пацієнтів з МС та О не мають такого розподілу значень, що давав би основу діагностувати гіперглікемію чи гіперінсулінемію. Але вод-

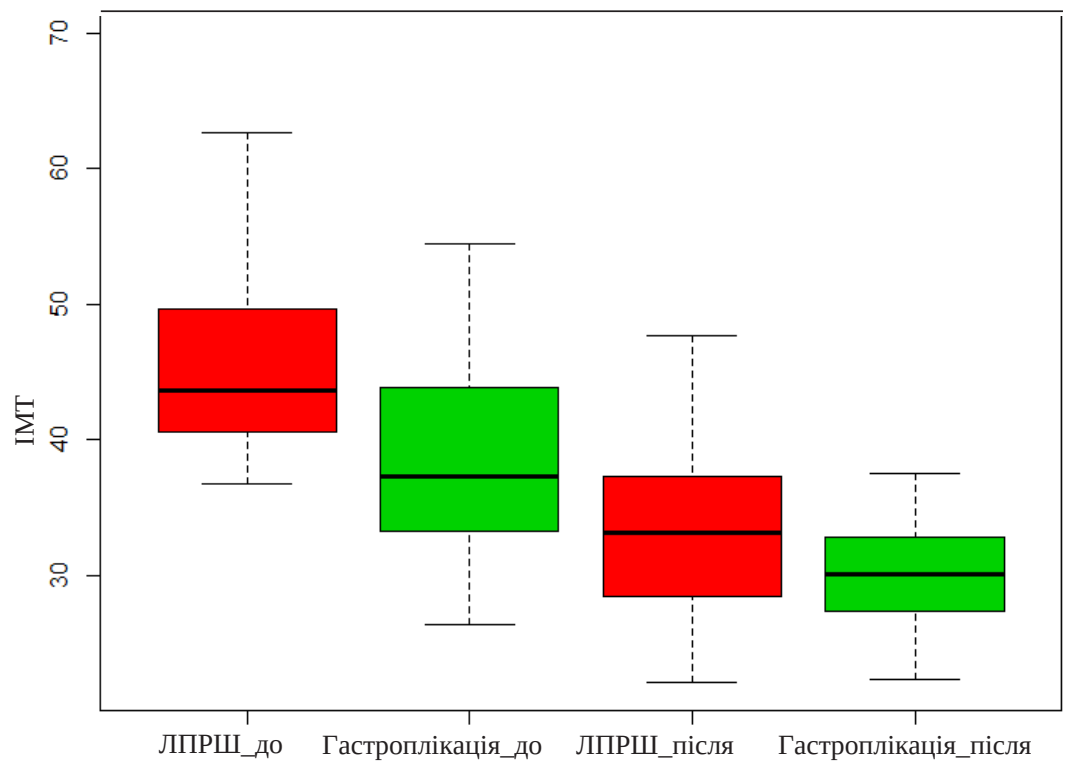

Рис. 2. Розподіл значень індексу маси тіла пацієнтів до і після операції. 


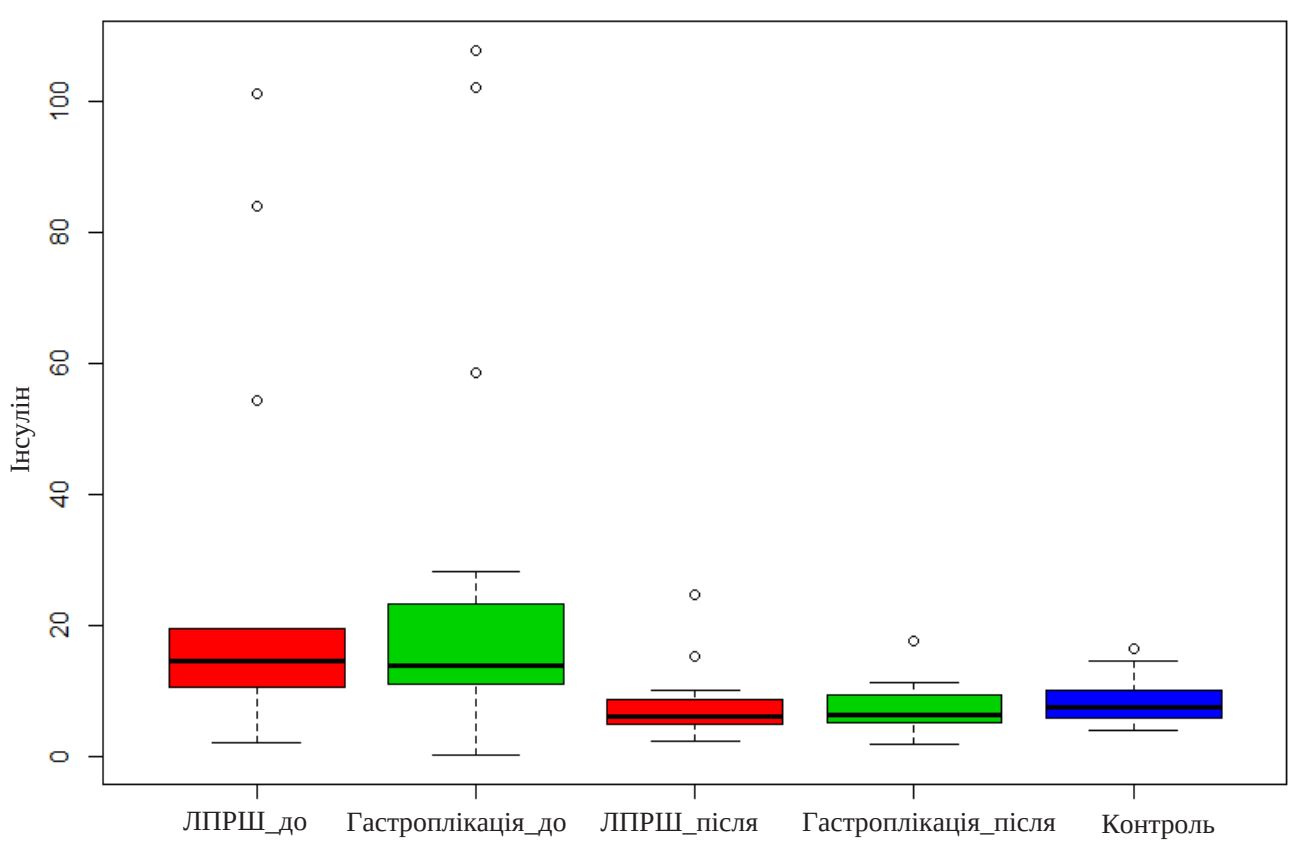

Рис. 3. Розподіл значень інсуліну до і після операції.

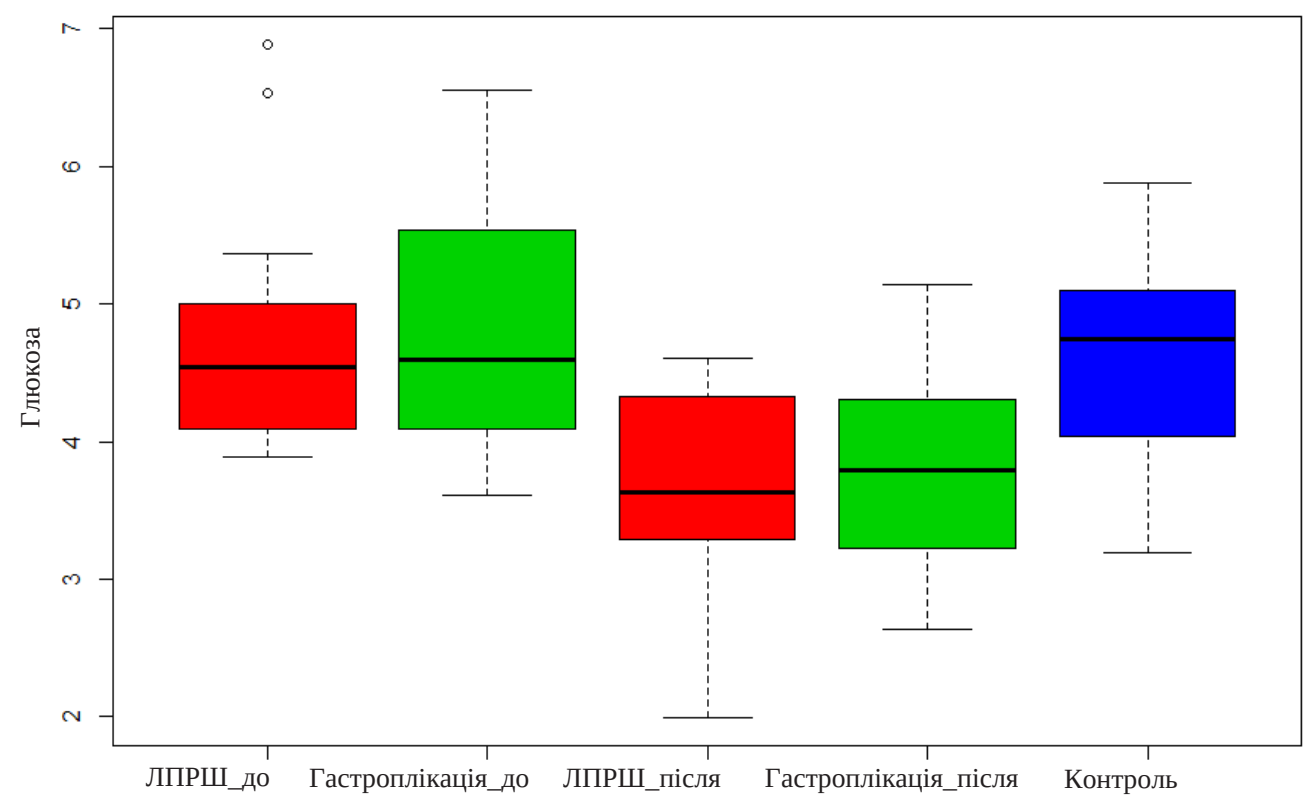

Рис. 4. Розподіл значень глюкози до і після операції.

ночас співвідношення цих показників (у вигляді індексу HOMA-IR) свідчить про існування інсулінорезистентності, яка створює умови для розвитку багатьох мортальних захворювань (діабет другого типу, артеріальна гіпертензія, системна ендотеліальна дисфункція). Але інсулінорезистентність простежується лише у передопераційному періоді, коли індекс HOMA-IR перевищував норму в групі з гастроплікацією на 108,6 \%, а в групі з ЛПРШ - на 115,2 \%. Після виконання рестриктивних баріатричних операцій показник інсулінорезистентності повністю нормалізувався, сягаючи середніх фізіологічних значень, що свідчить про відновлення чутливості рецепторного апарату до інсуліну і нівелювання ризику розвитку мортальних ускладнень.

Оцінка зміни показників у структурі супутніх захворювань (артеріальна гіпертензія, біль у суглобах) не мала достовірних відмінностей і в обох групах була позитивного характеру.

Аналіз ускладнень в обох групах показав відсутність значущих проблем у перебігу післяопераційного періоду, а наявні незначні відмінності не мають дискусійного інтересу. 
Висновки. Позитивні зміни в стані інсуліносенситивності, які корелюють із втратою маси, зменшенням IMT та нормалізацією маси тіла, дозволяють вважати рестриктивні баріатричні

\section{СПИСОК ЛІТЕРАТУРИ}

1. Можливості хірургічної корекції метаболічного синдрому у хворих з ожирінням / А. С. Лаврик, О. С. Тивончук, О. П. Дмитренко, О. А. Лаврик // Практ. ангіологія. - 2012. № 5-6. - C. 30-36.

2. The Dark Side of Testosterone Deficiency: I. Metabolic Syndrome and Erectile Dysfunction / A. M. Traish, A. Guay, R. Feeley [et al.] // Journal of Andrology. - 2009. - Vol. 30 (1). - P. 10-22.

3. https://ru.wikipedia.org/wiki/Метаболический_синдром

4. Branca F. The challenge of obesity in the European Region and the strategies for response / F. Branca, H. Nikogosian, T. Lobstein. - Copenhagen: World Health Organization Regional Office for Europe, 2007. - P. 1-293.

5. James W.P. The epidemiology of obesity: the size of the problem/ W. P. James // J. Intern. Med. - 2008. - No. 4. - P. 52-336.

6. Metabolic Syndrome and Non-Cardiac Vascular Diseases: an Update from Human Studies / N. Katsiki, V. G. Athyros, A. Karagiannis [et al.] // Curr. Pharm. Des. - 2013 [Epub ahead of print].

7. Is bariatric surgery necessary after intragastric balloon treatment? / L. Angrisani, M. Lorenzo, V. Borrelli [et al.] // Obes. Surg. - 2006. - No. 9 (16). - P. 7-1135.

8. Specific effects of biliopancreatic diversion on the major components of metabolic syndrome / N. Scopinaro, G. Marinari, операції патогенетично обгрунтованими та ефективними при попередженні розвитку мортальних ускладнень при метаболічному синдромі та ожирінні.

F. Papadia, G. Adami // Diabetes care. - 2005. - Vol. 28. P. 2406-2411.

9. Проблеми цукрового діабету в аспекті хірургічного лікування морбідного ожиріння / В. Ф. Саєнко, А. С. Лаврик, А. С. Тивончук, О. Ф. Бубало : матеріали з'їзду ендокринологів України // Ендокринологія. - 2001. - № 6 (додаток). C. 163.

10. Do incretins play a role in the remission of type 2 diabetes after gastric bypass surgery: what are the evidence? / M. Bose, B. Olivan, F. Pi-Sunyer [et al.] // Obes. Surg. - 2009. - Vol. 19(2). - P. 217-229.

11. A comparison of a personal series of biliopancreatic diversion and literature data on gastric bypass help to explain the mechanisms of resolution of type 2 diabetes by the two operations / N. Scopinaro, F. Papadia, G. Camerini [et al.] // Obes. Surg. 2008. - Vol. 18(8). - P. 1035-1038.

12. http://www.worldgastroenterology.org/UserFiles/file/guide lines/obesity-russian-2009.pdf

13. Бахрушин В. Є. Методи аналізу даних / В. Є. Бахрушин. - Запоріжжя : КПУ, 2011. - 268 с.

14. Бахрушин В. Є. Побудова описової статистики складних систем та графічне зображення даних за допомогою мови програмування R / В. Є. Бахрушин, М.О.Ігнахіна // Складні системи і процеси. - 2012. - № 2. - С. 3-11.

Отримано 29.07.16 